\title{
Drug-Induced Aortic Aneurysms, Ruptures and Dissections
}

\author{
Olav Spigset \\ Department of Clinical Pharmacology, St. Olav University Hospital, Trondheim, \\ Department of Laboratory Medicine, Children's and Women's Disease, \\ Norwegian University of Science and Technology, Trondheim,
}

Norway

\section{Introduction}

Both prescription drugs and illicit substances have been associated with the formation of aortic aneurysms, ruptures of aortic aneurysms, and acute aortic dissections. Most of the clinical information exists as single case reports and case series, but causal relationships have for many drug groups been substantiated on the basis of the known mechanisms of action of the drugs as well as from experimental studies in animals.

For abdominal aneurysms, the most important etiologic factors include systemic hypertension, hyperlipidemia and atherosclerosis. In theory, all drugs having a negative impact of one or more of these factors might increase the risk of aortic aneurysms. On the other hand, drugs positively influencing these factors, such as antihypertensives and cholesterol-lowering drugs, could, at least in theory, have a potentially protective effect on the formation and development of the aneurysms. For aortic dissections, systemic hypertension is a central risk factor, and many drugs known to increase systemic blood pressure abruptly are associated with aortic dissections. In addition, abrupt discontinuation of antihypertensive drugs known to cause rebound hypertension, such as the beta blockers, may precipitate aortic dissections.

The objective of this chapter is to present a comprehensive review of pharmaceutical products and illicit substances associated with the formation and ruptures of aortic aneurysms. Moreover, drugs implicated in acute aortic dissections are also included. Data from case reports and case series are tabulated for completeness. When relevant, these data are also synthesised in order to provide aggregate information, attempting to identify potential drug-specific risk factors. Results from experimental studies are included to provide an understanding of the underlying mechanisms, and treatment options are discussed when they deviate from conventional therapy.

\section{Methods}

This chapter is a literature review based upon the author's research experience with adverse drug reactions, supplied by a search in the database PubMed, primarily by using the medical subject heading (MeSH) term "aortic aneurysm" with the subheading "chemically 
induced". Such a search strategy revealed 185 articles, which were scrutinised. The reference lists in the articles were further checked to identify other studies and reports of interest.

\section{Drugs associated with aortic aneurysms}

\subsection{Glucocorticoids}

Ruptures of aortic aneurysms are not unknown in autoimmune disorders affecting connective tissue in various organ systems including blood vessels, such as systemic lupus erythematosus (SLE) and rheumatoid arthritis (Smith \& Hirst, 1979; Sato et al., 2003; Ohara et al., 2000a, $2000 \mathrm{~b}$ ). In such cases glucocorticoids may have a protective effect by inhibiting the activity of the underlying disorder. However, it has also been suspected that glucocorticoid use could have a precipitating role by increasing blood pressure, blood cholesterol and blood glucose levels, thereby causing atherosclerosis, as well as by increasing the fragility of blood vessels due to its negative effects on collagen formation and connective tissue strength (Smith \& Hirst, 1979; Sato et al., 2003; Ohara et al., 2000a, 2000b).

In the literature, a total of 14 cases have been reported after long-term glucocorticoid use in patients with autoimmune disorders affecting connective tissue (Table 1). In these cases, it is by no means obvious whether the rupture is caused by the underlying disease, the treatment with glucocorticoids, or a combination thereof. There are no reports of ruptured aortic aneurysms during long-term treatment with glucocorticoids for disorders and conditions not affecting connective tissue, such as glomerulonephritis, or after organ transplantations. However, there are in addition two cases of ruptures after short-term treatment with glucocorticiods for disorders not causing weakness of connective tissue (Mellingsæter et al., 2009), but on the other hand, these patients also had additional risk factors, such as advanced age (Table 1).

The gender distribution of the 16 cases identified in the literature (Table 1), with $50 \%$ males and $50 \%$ females, seems to reflect the gender distribution of the underlying disorders. As expected, the mean age is also relatively low, 56 years.

Experimental evidence of an association between the use of glucocorticoids and aortic aneurysm rupture is found in an animal study (Reilly et al., 1990). In that study, genetically susceptible mice had a higher risk of developing aortic aneurysms, as well as having a rupture of the aneurysms, when treated with hydrocortisone. When the genetically susceptible mice were given hydrocortisone for 14 days, the mean aortic diameter increased to $1.86 \mathrm{~mm}$, as compared to a stable value of $0.93 \mathrm{~mm}$ in a control group of genetically normal mice. In another experiment presented in the same publication (Reilly et al., 1990), nine of the 10 genetically susceptible mice died during the 21-day trial with hydrocortisone (6 with proven aortic rupture, 3 with presumed rupture), and also the 10th mouse in this group had an aneurysm after 21 days. The death risk was dose-dependent, with an average survival of 14 days among mice receiving the two higher hydrocortisone doses, as compared to 18-21 days among mice receiving the two lower doses.

In conclusion, long-term treatment with glucocorticoids has been associated with aortic aneurysm ruptures in numerous case reports, but it is not clear whether the ruptures have been caused by the underlying disease, the drug treatment, or combinations thereof. However, based on the known pharmacological effects of glucocorticoids as well as an experimental study, a causal association is not unlikely, although published evidence implies that this adverse drug reaction is very infrequent. 


\begin{tabular}{|c|c|c|c|c|}
\hline Reference & $\begin{array}{c}\text { Age, } \\
\text { gender }\end{array}$ & $\begin{array}{c}\text { Drug, dose, duration } \\
\text { of treatment }\end{array}$ & $\begin{array}{c}\begin{array}{c}\text { Location of the } \\
\text { aneurysm }\end{array} \\
\end{array}$ & $\begin{array}{l}\text { Underlying disease/ } \\
\text { predisposing factors }\end{array}$ \\
\hline $\begin{array}{c}\text { Smith } \\
\text { et al., } 1979\end{array}$ & $\begin{array}{c}55, \\
\text { male }\end{array}$ & $\begin{array}{l}\text { Prednisolone } 10 \mathrm{mg} / \mathrm{d} \\
\text { for } 11 \text { years }\end{array}$ & $\begin{array}{c}\text { Descending } \\
\text { thoracal }\end{array}$ & Rheumatoid arthritis \\
\hline $\begin{array}{c}\text { Smith } \\
\text { et al., } 1979\end{array}$ & $\begin{array}{c}68, \\
\text { female }\end{array}$ & $\begin{array}{l}\text { Prednisolone } 15 \mathrm{mg} / \mathrm{d} \\
\text { for "many years" }\end{array}$ & $\begin{array}{c}\text { Descending } \\
\text { thoracal }\end{array}$ & Rheumatoid arthritis \\
\hline $\begin{array}{l}\text { Stehbens } \\
\text { et al., } 1993\end{array}$ & $\begin{array}{c}56, \\
\text { male }\end{array}$ & $\begin{array}{c}\text { Glucocorticoids (NS) } \\
\text { for } 16 \text { years }\end{array}$ & Infrarenal & SLE \\
\hline $\begin{array}{c}\text { Seyama } \\
\text { et al., } 1989\end{array}$ & $\begin{array}{c}54, \\
\text { male }\end{array}$ & $\begin{array}{c}\text { Glucocorticoids (NS) } \\
\text { for } 1.5 \text { years }\end{array}$ & $\begin{array}{c}\text { Upper } \\
\text { abdominal }\end{array}$ & SLE \\
\hline $\begin{array}{c}\text { Kurata } \\
\text { et al., } 1985\end{array}$ & $\begin{array}{c}43, \\
\text { female }\end{array}$ & $\begin{array}{c}\text { Glucocorticoids (NS) } \\
\text { for } 10 \text { years }\end{array}$ & $\begin{array}{c}\text { Descending } \\
\text { thoracal }\end{array}$ & SLE \\
\hline $\begin{array}{l}\text { Higashina } \\
\text { et al., } 1990\end{array}$ & $\begin{array}{c}33, \\
\text { female }\end{array}$ & $\begin{array}{c}\text { Glucocorticoids (NS) } \\
\text { for } 18 \text { years }\end{array}$ & $\begin{array}{c}\text { Descending } \\
\text { thoracal }\end{array}$ & SLE \\
\hline $\begin{array}{c}\text { Sato } \\
\text { et al., } 1995^{1}\end{array}$ & $\begin{array}{c}45, \\
\text { female }\end{array}$ & $\begin{array}{l}\text { Glucocorticoids (NS) } \\
\text { for } 27 \text { years }\end{array}$ & Infrarenal & $\begin{array}{c}\text { Progressive systemic } \\
\text { sclerosis }\end{array}$ \\
\hline $\begin{array}{c}\text { Sato } \\
\text { et al., } 19951,2\end{array}$ & $\begin{array}{c}52, \\
\text { female }\end{array}$ & $\begin{array}{c}\text { Glucocorticoids }(\mathrm{NS}) \\
\text { mean } 3.5 \mathrm{mg} / \mathrm{d} \text { for } \\
16 \text { years }\end{array}$ & $\begin{array}{c}\text { Descending } \\
\text { thoracal/ } \\
\text { infrarenal } \\
\end{array}$ & SLE \\
\hline $\begin{array}{c}\text { Sato } \\
\text { et al., } 1995^{1} \\
\end{array}$ & $\begin{array}{c}73, \\
\text { female }\end{array}$ & $\begin{array}{c}\text { Glucocorticoids (NS) } \\
\text { for } 15 \text { years }\end{array}$ & Infrarenal & $\begin{array}{l}\text { Rheumatoid arthritis; } \\
\text { advanced age }\end{array}$ \\
\hline $\begin{array}{c}\text { Sato } \\
\text { et al., } 19951,2\end{array}$ & $\begin{array}{c}75, \\
\text { female }\end{array}$ & $\begin{array}{c}\text { Glucocorticoids (NS), } \\
\text { mean } 3.2 \mathrm{mg} / \mathrm{d} \text { for } \\
32 \text { years } \\
\end{array}$ & Infrarenal & SLE; advanced age \\
\hline $\begin{array}{c}\text { Sato } \\
\text { et al., } 1995^{1,2}\end{array}$ & $\begin{array}{c}43, \\
\text { female }\end{array}$ & $\begin{array}{c}\text { Glucocorticoids }(\mathrm{NS}), \\
\text { mean } 2.8 \mathrm{mg} / \mathrm{d} \text { for } \\
22 \text { years }\end{array}$ & Infrarenal & SLE \\
\hline $\begin{array}{c}\text { Ohara } \\
\text { et al., 2000a }\end{array}$ & $\begin{array}{l}34, \\
\text { male }\end{array}$ & $\begin{array}{c}\text { Glucocorticoids (NS), } \\
\text { mean } 4.1 \mathrm{mg} / \mathrm{d} \text { for } \\
21 \text { years } \\
\end{array}$ & Infrarenal & SLE \\
\hline $\begin{array}{c}\text { Ohara } \\
\text { et al., 2000b }\end{array}$ & $\begin{array}{l}73, \\
\text { male }\end{array}$ & $\begin{array}{c}\text { Glucocorticoids (NS), } \\
\text { mean } 2.5 \mathrm{mg} / \mathrm{d} \text { for } \\
1 \text { year }\end{array}$ & Infrarenal & SLE; advanced age \\
\hline $\begin{array}{l}\text { Hussain } \\
\text { et al., } 1998\end{array}$ & $\begin{array}{c}40, \\
\text { male }\end{array}$ & $\begin{array}{c}\text { Glucocorticoids (NS) } \\
\text { for } 15 \text { years }\end{array}$ & $\begin{array}{l}\text { Ascending } \\
\text { thoracal }\end{array}$ & SLE \\
\hline $\begin{array}{l}\text { Melling- } \\
\text { sæter } \\
\text { et al., } 2009\end{array}$ & $\begin{array}{l}77, \\
\text { male }\end{array}$ & $\begin{array}{l}\text { Prednisolone } 40 \mathrm{mg} / \mathrm{d} \\
\text { for } 4 \text { days }\end{array}$ & $\begin{array}{l}\text { Descending } \\
\text { thoracal }\end{array}$ & $\begin{array}{c}\text { Pyoderma } \\
\text { gangrenosum/ } \\
\text { advanced age; } \\
\text { previous aorta } \\
\text { aneurysm }{ }^{3}\end{array}$ \\
\hline $\begin{array}{l}\text { Melling- } \\
\text { sæter } \\
\text { et al., } 2009 \\
\end{array}$ & $\begin{array}{l}82, \\
\text { male }\end{array}$ & $\begin{array}{c}\text { Prednisolone } 60 \mathrm{mg} / \mathrm{d} \\
\text { for } 9 \text { days and } \\
30 \mathrm{mg} / \mathrm{d} \text { for } 5 \text { days }\end{array}$ & Abdominal & $\begin{array}{l}\text { Bullous pemphigoid/ } \\
\text { advanced age }\end{array}$ \\
\hline
\end{tabular}

Abbreviations: NS = not specified; SLE = systemic lupus erythematosus

1 The same case is also included in the case series by Ohara et al., 2000a

2 The same case is also included in the case series by Ohara et al., 2000b

${ }^{3}$ Previously treated with a stent graft in the abdominal part of a thoraco-abdominal aortic aneurysm

Table 1. Published cases of glucocorticoid-associated aortic aneurysm ruptures 


\subsection{Antihypertensive drugs}

Based upon evidence from animal studies, activation of the renin-angoitensin-aldosteron system seems to be a central factor in the development of aortic aneurysms (Daugherty et al., 2006; Lu et al., 2008; Miyake \& Morishita, 2009). In a population-based case-control study of more than 15,000 patients with abdominal aortic aneurysms (3,379 with ruptures and 11,974 without ruptures), treatment with angiotensin converting enzyme (ACE) inhibitors before admission was associated with a reduced risk of ruptures (adjusted Odds Ratio [OR] 0.83 ; $95 \%$ confidence interval [CI] 0.73-0.95). In contrast, protective effects were not found for beta-blockers, calcium antagonists, alpha-blockers or thiazide diuretics. Thus, the beneficial effect of ACE inhibitors on the risk of ruptures seems to be independent of the antihypertensive effect (Hackam et al., 2006). Those who during the last months had discontinued treatment with ACE inhibitors, had on the other hand a marginally higher risk of ruptures (adjusted OR 1.39; $95 \%$ CI 1.09-1.77). In contrast to the above findings, angiotensin receptor blockers (ARBs), which also inhibit the renin-angoitensin-aldosteron system, were not found to have any protective effect (adjusted OR 1.24; 95 \% CI 0.71-2.18). However, this apparent discrepancy may be caused by a type II error, as only 132 patients in the entire material used ARBs (Hackam et al., 2006).

Inconsistent with the ACE inhibitor findings cited above, a recent prospective cohort study of 1,701 patients with small abdominal aortic aneurysms found that the growth rate of the aneurysms in fact was higher $(3.33 \mathrm{~mm} /$ year $)$ in the 169 patients treated with ACE inhibitors than in the remaining patients $(2.77 \mathrm{~mm} /$ year; $\mathrm{p}=0.009)$ (Sweeting et al., 2010). No such associations were found for other groups of antihypertensive drugs.

It should also be noted that in a case-control study, use of calcium antagonists was significantly associated with the occurrence of aortic aneurysms (adjusted OR 2.6; $95 \%$ CI 1.5-4.2), whereas no other antihypertensive drug groups showed an increased risk (Wilmink et al., 2002). In the same study, patients exposed to calcium antagonists also had an increased aortic wall stiffness. Nevertheless, there was no association between calcium antagonists (or with any of the other drug groups) and the growth rate of the aneurysms after they had been detected. The association between calcium antagonist use and the occurrence of aortic aneurysms is consistent with the finding in an animal study in which the calcium antagonist amlodipine accelerated the degradation of elastin (Boyle et al., 1998).

All observational studies, including those cited above, are inevitably subject to bias and confounding. Thus, there is an urgent need for prospective, randomised, controlled trials to elucidate the role of both ACE inhibitors, ARBs, calcium antagonists and other groups of antihypertensives as to whether they have a protective, neutral or provoking effect on the formation and growth of aortic aneurysms and the risk of ruptures.

\section{Drugs assosiated with aortic dissections}

\subsection{Phosphodiesterase-5 inhibitors}

The phospodiesterase-5 (PDE-5) inhibitors sildenafil, tadalafil and vardenafil are widely used to cause penile erection in patients with impotence. An association between sildenafil and acute aortic dissection has been suspected in three case reports (Table 2). Hitherto, no cases have been reported for tadalafil and vardenafil.

As all the three patients reported in the literature had predisposing factors for aortic dissection (Table 2), the causal role of sildenafil has been questioned. One patient used 
isosorbide mononitrate concomitantly. Combinations of PDE-5 inhibitors with nitrates and other nitric oxide donors, including nitroglycerin and isosorbide mono- or dinitrate, are contraindicated due to the risk of excessive increases in systemic blood pressure. Also sexual arousal is associated with increased blood pressure, which could have been a contributing factor. However, at least in one of the patients, the aortic dissection appeared before sexual intercourse took place.

\begin{tabular}{|c|c|c|c|c|c|}
\hline Reference & $\begin{array}{c}\text { Age, } \\
\text { gender }\end{array}$ & Drug, dose & $\begin{array}{c}\text { Temporal } \\
\text { relationship }\end{array}$ & Predisposing factors & $\begin{array}{c}\text { Stanford } \\
\text { type 1 }\end{array}$ \\
\hline $\begin{array}{c}\text { Famularo } \\
\text { et al., 2001 }\end{array}$ & 42 , male & $\begin{array}{c}\text { Sildenafil } \\
50 \mathrm{mg}\end{array}$ & $\begin{array}{c}1 \text { hour after } \\
\text { intake }\end{array}$ & $\begin{array}{c}\text { Cocaine sniffing 2 hours } \\
\text { earlier, heavy smoker }\end{array}$ & $\mathrm{B}$ \\
\hline $\begin{array}{c}\text { Nachtnebel } \\
\text { et al., 2006 }\end{array}$ & 61 , male & $\begin{array}{c}\text { Sildenafil } \\
50 \mathrm{mg}\end{array}$ & $\begin{array}{c}30 \text { min after } \\
\text { intake }\end{array}$ & $\begin{array}{c}\text { Hypertension, } \\
\text { concomitant use of } \\
\text { isosorbide mononitrate }\end{array}$ & $\mathrm{A}$ \\
\hline $\begin{array}{c}\text { Tiryakioglu } \\
\text { et al., 2009 }\end{array}$ & 28, male & $\begin{array}{c}\text { Sildenafil } \\
50 \mathrm{mg}\end{array}$ & $\begin{array}{c}\text { 2 hours after } \\
\text { intake }\end{array}$ & $\begin{array}{c}\text { Bicuspid aortic valve with } \\
\text { ascending aortic } \\
\text { aneurysm }\end{array}$ & $\mathrm{A}$ \\
\hline
\end{tabular}

${ }^{1}$ Stanford type A: All dissections involving the ascending aorta, regardless of the site of origin.

Stanford type B: All dissections not involving the ascending aorta

Table 2. Published cases of phosphodiesterase-5-associated aortic dissections

In addition to the risk of increasing systemic blood pressure, at least when combined with nitrates and other nitric oxide donors, sildenafil has vasorelaxant and antiproliferative effects on pulmonary vascular smooth muscle cells. Due to these effects it is also used in patients with pulmonary hypertension. Although not substantiated experimentally, it has been speculated that a similar antiproliferative effect in the aorta as in the pulmonary artery might cause a thinner media due to smooth muscle cell loss, rendering the aortic wall more vulnerable to dissections (Nactnebel et al., 2006).

In conclusion, sildenafil and possibly also other PDE-5 inhibitors have the potential to increase systemic blood pressure in certain situations, thus being able to provoke aortic dissections in vulnerable individuals.

\subsection{Vascular endothelial growth factor inhibitors}

Vascular endothelial growth factor (VEGF) inhibitors are a drug group inhibiting vascular proliferation and promoting apoptosis of cells participating in the formation of new blood vessels. As VEGF expression is increased in a variety of tumors, VEGF inhibitors are primarily used in the treatment of malignant diseases. An association between acute aortic dissection and treatment with the VEGF inhibitors sorafenib, sunitinib and bevacizumab has been suspected on the basis of three case reports, summarised in Table 3 .

Hypertension is one of the major adverse drug reactions of VEGF inhibitors. For sorafenib and sunitinib, overall incidences of 23.4 and $22.5 \%$ have been reported in meta-analyses (Wu et al., 2008). For bevacizumab, the incidence of hypertension in studies included in a meta-analysis ranged from $2.7 \%$ to $32 \%$ during low-dose treatment and between $17.6 \%$ and $36 \%$ during high-dose treatment (Zhu et al., 2007). In most cases, the increased blood pressure can be treated with antihypertensive drugs, but a minority of patients will not respond to antihypertensive therapy and the VEGF inhibitor has to be discontinued. 


\begin{tabular}{|c|c|c|c|c|c|}
\hline Reference & $\begin{array}{c}\text { Age, } \\
\text { gender }\end{array}$ & Drug & $\begin{array}{c}\text { Temporal } \\
\text { relationship }\end{array}$ & Predisposing factors & $\begin{array}{c}\text { Stanford } \\
\text { type }^{1}\end{array}$ \\
\hline $\begin{array}{c}\text { Aragon- } \\
\text { Ching } \\
\text { et al., 2008 }\end{array}$ & $\begin{array}{c}70, \\
\text { male }\end{array}$ & $\begin{array}{c}\text { Bevaci- } \\
\text { zumab }\end{array}$ & $\begin{array}{c}\text { After } 28 \\
\text { cycles of be- } \\
\text { vacizumab } \\
\text { for } 21 \text { days }\end{array}$ & $\begin{array}{c}\text { Hypertension for 25 } \\
\text { years, increased } \\
\text { considerably after 10 } \\
\text { months of bevacizumab } \\
\text { treatment }\end{array}$ & B \\
\hline $\begin{array}{c}\text { Edeline } \\
\text { et al., 2010 }\end{array}$ & $\begin{array}{c}58, \\
\text { male }\end{array}$ & Sunitinib & $\begin{array}{c}\text { After } 4 \\
\text { cycles of } \\
\text { sunitinib for } \\
28 \text { days }\end{array}$ & $\begin{array}{c}\text { None; no increase in } \\
\text { systemic blood pressure } \\
\text { observed during sunitinib } \\
\text { treatment }\end{array}$ & B \\
\hline $\begin{array}{c}\text { Serrano } \\
\text { et al., 2010 }\end{array}$ & $\begin{array}{c}\text { After 3 } \\
\text { female }\end{array}$ & Sorafenib & $\begin{array}{c}\text { cycles of } \\
\text { sorafenib for } \\
21 \text { days }\end{array}$ & Advanced age & B \\
\hline
\end{tabular}

${ }^{1}$ Stanford type A: All dissections involving the ascending aorta, regardless of the site of origin. Stanford type B: All dissections not involving the ascending aorta

Table 3. Published cases of vascular endothelial growth factor inhibitor-associated aortic dissections

The pathogenetic mechanism behind VEGF inhibitor-induced hypertension remains uncertain. It has been suggested that as VEGF inhibitors also block the effects of other growth factors including platelet-derived growth factor (PDGF), and as PDGF plays a role in blood vessel tonus regulation and microvascularisation, this could be a possible mechanism (Edeline et al., 2010). However, closely related protein kinase inhibitors such as imatinib, dasatinib and nilotinib, which inhibits PDGF without inhibiting VEGF, are not particularly linked to hypertension. On this basis, a direct effect via VEGF inhibition seems more likely. The involvement of VEGF in the formation of normal blood vessels during embryonic development and in the carcinogenesis is well studied, but its possible function in normal blood vessels in adults is unclear. Suggested mechanisms include impaired angiogenesis at the microcirculation level, endothelial dysfunction associated with decreased levels of the vasodilator nitric oxide which is normally stimulated by VEGF, and alterations in the reninangiotensin-aldosteron system (Sica, 2006).

Based upon the high incidence of hypertension during treatment with VEGF inhibitors, patients treated with these drugs should be closely followed with blood pressure measurements. If hypertension develops, it should be treated adequately. Obviously, as hypertension is a well-known risk factor for aortic dissection, also VEGF inhibitor-induced hypertension will increase the risk of aortic dissection.

\subsection{Antihypertensive drugs}

Antihypertensive drugs are known to protect a vulnerable aorta from dissections, and discontinuation of such drugs could therefore be expected to increase the risk of acute dissections. In particular antihypertensive drugs for which rebound hypertension occur after abrupt discontinuation, such as beta-blockers and clonidine, would be expected to increase the risk of aortic dissections. 
One single case of acute aortic dissection has been reported within a short time interval after abrupt discontinuation of antihypertensive drug treatment (Eber et al., 1993). A 60year-old man treated with beta-blockers for hypertension for 20 years developed a Stanford type A dissection two days after stopping metoprolol. It is not explicitly stated in the report whether the drug was tapered down before discontinuation or stopped abruptly, but is seems likely that treatment ceased directly from a dose of 50-100 mg/day. In such cases rebound effects including increased blood pressure, tachycardia and cardiac arrhythmias, and in some cases even cardiac infarction and sudden cardiac death, may occur (Houston \& Hodge, 1988; Psaty et al., 1990). Therefore, current recommendations state that beta-blockers (and clonidine) should be tapered over at least 1-2 weeks before discontinuation.

\subsection{Other drugs}

Anticoagulants and fibrinolytic drugs have in two case reports been associated with aortic dissections and ruptures of thoracic aortic aneurysms. The first case was an 80-year-old woman who developed a Stanford type B aortic dissection during treatment with warfarin (Blunt \& Impallomeni, 2004). Notably, her International Normalised Ratio (INR) was 4.8, indicating a considerably increased bleeding risk. The authors speculate that the underlying mechanism was a bleeding into an atheromatous plaque in the thoracic aorta. The second case was a 67-year-old man who was treated with the tissue plasminogen activator (t-PA) nateplase due to an acute ischemic stroke and who developed a rupture of a thoracic aortic aneurysm (Hayashi et al., 2004). The authors suggest that the t-PA infusion caused the rupture, based upon some evidence that plasminogen activators are able to degrade abdominal aortic aneurysms (Reilly, 1996).

A single case report of aortic dissection exists in a patient receiving chemotherapy for cancer (Golden et al., 1997). The patient was a 42-year-old man treated with cyclophosphamide, vincristine, procarbazine, prednisolone, bleomycin and vinblastine for Hodgkin's disease. As many of these agents are known to cause endothelial cell damage, the authors postulate that a toxic effect to endothelial cells in the aortic wall was the underlying mechanism. However, the patient also had other risk factors, including hypercholesterolemia and tobacco smoking. Thus, a causal relationship between the cytotoxic drugs and the aortic dissection remains obscure, and, if the suggested underlying mechanism is correct, it is remarkable that no more reports are found in the literature.

Numerous other drugs than those presented earlier in this review have the ability of causing hypertension. Consequently, these drugs might, at least in theory, increase the risk of aortic dissections. Common for these drugs is that there are no published case reports of aortic dissections related to their use. Whether the reason for the lack of such reports is that the relationship has not been recognised, or it is that the excess risk is so low that it can be considered negligible, is unknown. Drugs known to increase systemic blood pressure include sympathomimetic substances like adrenaline, noradrenaline, dopamine, metaraminol and phenylephrine, which might cause excessive elevations in blood pressure when the dose or, when given as an infusion, the rate of infusion, is not carefully controlled. Other drugs known to cause hypertension as an adverse drug reaction include non-steroidal antiinflammatory drugs (NSAIDs), ciclosporin and venlafaxine, just to mention a few. Moreover, monoamine oxidase inhibitors induce excessive hypertension when indirectly acting sympathomimetic drugs or tyramine-rich food or beverages are ingested concomitantly (Davies \& Davies, 1998). 


\subsection{Illicit drugs}

\subsubsection{Cocaine}

The association between cocaine abuse and aortic dissection is well documented. In some case series of patients with aortic dissection the proportion caused by cocaine abuse is relatively high. For example, in a material from a US urban hospital, 14 of the 38 cases of aortic dissection registered between 1981 and 2000 (37\%) were related to cocaine use (Hsue et al., 2002). In another US study, (Singh et al., 2007), 13 of 46 cases (28\%) diagnosed between 1996 and 2005 were associated with cocaine. Finally, in a chart review for the period 1990-2006, 16 of 163 patients (9.8\%) had used cocaine the last 24 hours before symptom onset (Daniel et al., 2007). In contrast, only $0.5 \%$ of the cases in the International Registry for Aortic Dissection were found to be related to cocaine (Eagle et al., 2002). The proportion found to be caused by cocaine abuse will clearly depend on the frequency of cocaine use in the population from which the subjects originate. Moreover, cases associated with cocaine use will not be revealed if the patients are not explicitly asked about cocaine use or preferably tested for the presence of the cocaine metabolite benzoylecgonine in urine. In addition to these four more systematic studies (Hsue et al., 2002; Eagle et al., 2002; Daniel et al., 2007; Singh et al., 2007), numerous single cases, summarised in Table 4, are reported in the literature.

Based on the 16 cases detailed by Daniel et al. (2007) and the 19 cases presented in Table 4, subjects with cocaine-related aortic dissections seem to be younger than average. All were younger than 60 years of age, three of four were younger than 50 , and the mean age was 44 years. In total, $77 \%$ were males. Almost all were long-term users, many had a history of uncontrolled hypertension, and the dissections occurred shortly after intake of cocaine. In some cases, symptoms appeared during or within the first few minutes after ingestion, but there could also be a lag-time of up to 24 hours - with one possible exception; an apparent lagtime of 3 days is reported in one case (Divakaran et al., 2007). In both the studies by Hsue et al. (2002) and by Daniel et al. (2007), the mean lag-time was 12 hours. However, based upon the 19 single cases (Table 4), the median lag-time could be estimated to about 1.5-2 hours, only.

It has been suggested that Stanford type B dissections are more common among cocaine users than in the average population (Singh 2007). However, according to Daniel et al. (2007), it was not apparent that type B dissections were more common. Of the 16 cases presented by Daniel et al. (2007) plus the 19 case reports (Table 4), $54 \%$ were of type A whereas $46 \%$ were of type B. As a comparison, $62 \%$ were of type A and $38 \%$ of type B in a general material consisting of 464 patients with acute aortic dissection (Ince et al., 2007).

It has been claimed that both the recurrence risk and the mortality of aortic dissections could be higher among cocaine users than among subjects with dissections unrelated to cocaine use (Hsue et al., 2002). The most likely reason for a possibly increased recurrence risk is continued cocaine use after discharge; there is no data available indicating that the recurrence risk would be increased in patients able to seize cocaine abuse after the first episode of dissection.

The effects of cocaine on the cardiovascular system are caused by its sympathomimetic properties. Cocaine predominantly exerts its pharmacological effects by blocking the reuptake of noradrenaline and dopamine from the synaptic cleft into presynaptic neurons. Increased levels of noradrenaline in the synaptic cleft activate postsynaptic alpha-adrenergic and beta-adrenergic receptors. An enhanced release of noradrenaline into the synaptic cleft by cocaine may also take place, causing further receptor activation. Activation of alpha- 1 receptors in blood vessels causes elevation of the systemic blood pressure through vasoconstriction. Activation of beta-1 receptors in the heart promotes ventricular contractility and increases heart rate, thereby contributing to the effects on blood pressure. 


\begin{tabular}{|c|c|c|c|c|c|}
\hline Reference & $\begin{array}{l}\text { Age, } \\
\text { gender }\end{array}$ & $\begin{array}{c}\text { Route of } \\
\text { administration }\end{array}$ & $\begin{array}{l}\text { Interval between } \\
\text { intake and } \\
\text { symptom onset }\end{array}$ & $\begin{array}{l}\text { Predisposing } \\
\text { factors }\end{array}$ & $\begin{array}{l}\text { Stanford } \\
\text { type }^{1}\end{array}$ \\
\hline $\begin{array}{c}\text { Barth } \\
\text { et al., } 1986\end{array}$ & $\begin{array}{c}45, \\
\text { male }\end{array}$ & Inhalation & Hours & Hypertension & A \\
\hline $\begin{array}{l}\text { Edwards \& } \\
\text { Rubin, } 1987\end{array}$ & $\begin{array}{c}41, \\
\text { male }\end{array}$ & Insufflation & $30 \mathrm{~min}$ & Hypertension & B \\
\hline $\begin{array}{c}\text { Grannis } \\
\text { et al., } 1988 \\
\end{array}$ & $\begin{array}{c}46, \\
\text { male }\end{array}$ & Insufflation & 1.5 hours & Hypertension & B \\
\hline $\begin{array}{c}\text { Gadaleta } \\
\text { et al., } 1989\end{array}$ & $\begin{array}{c}45, \\
\text { male }\end{array}$ & Insufflation & Unknown & Hypertension & $\mathrm{A}$ \\
\hline $\begin{array}{c}\text { Fischer \& } \\
\text { Holroyd, } \\
1992 \\
\end{array}$ & $\begin{array}{l}58, \\
\text { male }\end{array}$ & Subcutaneously & $5 \mathrm{~min}$ & Hypertension & B \\
\hline $\begin{array}{c}\text { Om } \\
\text { et al., } 1992\end{array}$ & $\begin{array}{c}47, \\
\text { male }\end{array}$ & Intravenously & $\begin{array}{l}\text { Unknown; died } \\
\text { before surgery }\end{array}$ & Hypertension & A \\
\hline $\begin{array}{c}\text { Cohle \& Lie, } \\
1992\end{array}$ & $\begin{array}{c}35, \\
\text { male }\end{array}$ & Inhalation & $\begin{array}{c}\text { Unknown; found } \\
\text { dead }\end{array}$ & NR & $\mathrm{A}$ \\
\hline $\begin{array}{c}\text { Simons } \\
\text { et al., } 1992\end{array}$ & $\begin{array}{c}26, \\
\text { female }\end{array}$ & Insufflation & Unknown & NR & A \\
\hline $\begin{array}{c}\text { Adkins } \\
\text { et al., } 1993\end{array}$ & $\begin{array}{c}43, \\
\text { male }\end{array}$ & Inhalation & During smoking & NR & A \\
\hline $\begin{array}{l}\text { McDermott } \\
\text { et al., } 1993\end{array}$ & $\begin{array}{c}37, \\
\text { male }\end{array}$ & Inhalation & 12-18 hours & Hypertension & B \\
\hline $\begin{array}{c}\text { Sherzoy } \\
\text { et al., } 1994 \\
\end{array}$ & $\begin{array}{c}50, \\
\text { female }\end{array}$ & Inhalation & 2 hours & Hypertension & B \\
\hline $\begin{array}{c}\text { Rashid } \\
\text { et al., } 1996 \\
\end{array}$ & $\begin{array}{c}42, \\
\text { male }\end{array}$ & Inhalation & $40 \mathrm{~min}$ & Hypertension & A \\
\hline $\begin{array}{c}\text { Perron \& } \\
\text { Gibbs, } 1997\end{array}$ & $\begin{array}{c}33, \\
\text { male }\end{array}$ & Inhalation & Unclear & None & A \\
\hline $\begin{array}{l}\text { Hohm, } \\
1995\end{array}$ & $\begin{array}{c}28, \\
\text { male }\end{array}$ & NR & Unclear & None & A \\
\hline $\begin{array}{c}\text { Baumgartner } \\
\text { \& Omari, } \\
1997\end{array}$ & $\begin{array}{c}40, \\
\text { female }\end{array}$ & NR & NR & NR & A \\
\hline $\begin{array}{c}\text { Madu } \\
\text { et al., } 1999\end{array}$ & $\begin{array}{c}34, \\
\text { female }\end{array}$ & Inhalation & 2 hours & Hypertension & B \\
\hline $\begin{array}{l}\text { Divakaran } \\
\text { et al., } 2007\end{array}$ & $\begin{array}{c}45 \\
\text { male }\end{array}$ & NR & 3 days? & NR & A \\
\hline $\begin{array}{l}\text { Johnson } \\
\text { et al., } 2008\end{array}$ & $\begin{array}{c}48, \\
\text { male }\end{array}$ & Inhalation & "Short" & Hypertension & A \\
\hline $\begin{array}{c}\text { Szeberin } \\
\text { et al., } 2009\end{array}$ & $\begin{array}{c}35, \\
\text { male }\end{array}$ & NR & NR & NR & B \\
\hline
\end{tabular}

Abbreviations: $\mathrm{NR}=$ not reported

${ }^{1}$ Stanford type A: All dissections involving the ascending aorta, regardless of the site of origin.

Stanford type B: All dissections not involving the ascending aorta

Table 4. Published cases of cocaine-associated aortic dissections 
The sudden and considerable increase in blood pressure shortly after intake of cocaine obviously will increase shear stress in the aorta, sometimes causing a disruption of the intima and a dissection. More infrequently, the stress may produce an intramural hematoma that subsequently may rupture into the lumen (Scherzoy et al., 1994; Singh et al., 2010). In addition, long-term cocaine use may impair the elastic properties of the aorta, thereby reducing the ability of the aortic wall to withstand fluctuations in blood pressure and shear stress (Bigi et al., 2008).

As for aortic dissection of other causes, the immediate treatment of cocaine-induced dissections is to lower the blood pressure. In general, beta-blockers are most often used for this purpose. However, for cocaine-related dissections, beta-blockers should be avoided because they do not antagonise the alpha-adrenergic effects and may thus exacerbate, or at least not counteract, cocaine-related vasoconstriction of the coronary and visceral arteries (Lange et al., 1990; Hollander, 2008; Singh et al., 2010). The combined alpha- and betablocker labetalol would therefore, at least in theory, be a better choice. However, labetalol does not reverse the vasoconstriction of the coronary arteries fully, most likely because its alpha-antagonistic properties are too weak (Boehrer et al., 1993; Hollander, 2008). Nevertheless, some authors still recommend the use of labetalol. Alternative treatments include nitroglycerin, which reverse the cocaine-induced vasoconstriction of the coronary arteries to a sufficiently high degree, and verapamil (Lange \& Hills, 2001). Also nitroprusside and hydralazine have been suggested, although these drugs, which do not exert beta-blocking properties, in fact may increase the shear stress of the aorta further due to reflex tachycardia with a subsequent increase in cardiac output (Hollander, 2008; Singh et al., 2010).

\subsubsection{Methamphetamine, amphetamine and 3,4-methylenedioxymethamphetamine (MDMA; ecstasy)}

There are numerous case reports of acute aortic dissection related to methamphetamine, and a few case reports exist for the closely related agents amphetamine and 3,4methylenedioxymethamphetamine (MDMA; ecstasy) (Table 5). For simplicity, these three substances are described as "amphetamines" in this chapter. Among the 13 cases published in detail in the literature (Table 5), all were males. Their mean age was 38 years, and none were older than 52, thus resembling the situation for cocaine users and reflecting the characteristics of the population using these illicit drugs. In nine of the 11 cases where the type of dissection was reported $(81 \%)$, the dissections were Stanford type A.

In a systematic review of 35 deceased patients with aortic dissection screened for drug use in California during the years 1987-1996, seven (20 \%) tested positive for methamphetamine (Swalwell \& Davis, 1999). Whereas the mean age in the total group was 52 years, the mean age among those who tested positive for methamphetamine was 41 years. In six of the seven cases $(86 \%)$, the dissection was of type A. Thus, the characteristics of this group are similar to those of the 13 cases published in detail (Table 5).

In a population-based study of 3,116 aortic dissections in subjects aged 18 to 49 years (Westover \& Nakonezny, 2010), abuse and dependence of amphetamines were significantly associated with aortic dissections (OR 3.33, 95 \% CI 2.37-4.69). Interestingly, the OR for abuse and dependence of amphetamines was lower than for Marfan syndrome (OR = 374), cardiovascular syphilis $(\mathrm{OR}=106)$, bicuspid aorta valve $(\mathrm{OR}=45)$, Takayashu disease $(\mathrm{OR}=31)$, Turner syndrome $(\mathrm{OR}=22)$, Ehlers-Danlos syndrome $(\mathrm{OR}=13)$, giant cell 
arthritis $(\mathrm{OR}=6.5)$, hypertension $(\mathrm{OR}=7.7)$, coarctation of the aorta $(\mathrm{OR}=4.6)$ and motor vehicle accidents $(\mathrm{OR}=3.6)$, but higher than for cocaine abuse/dependence $(\mathrm{OR}=1.6)$, tobacco use $(\mathrm{OR}=1.4)$, and age $(\mathrm{OR}=1.1)$. The higher risk for the amphetamines than for cocaine is somewhat surprising on the basis of the number of published cases in the literature. One possible explanation for the increased risk might be that the amphetamines most likely have a prolonged effect on the blood pressure increments as compared to cocaine, due to a slower elimination from the body.

\begin{tabular}{|c|c|c|c|c|c|}
\hline Reference & $\begin{array}{c}\text { Age, } \\
\text { gender }\end{array}$ & Drug & $\begin{array}{c}\text { Temporal } \\
\text { relationship }\end{array}$ & $\begin{array}{c}\text { Predisposing } \\
\text { factors }\end{array}$ & $\begin{array}{c}\text { Stanford } \\
\text { type }\end{array}$ \\
\hline $\begin{array}{c}\text { Davis \& } \\
\text { Swalwell, } 1994\end{array}$ & $\begin{array}{c}52, \\
\text { male }\end{array}$ & Methamphetamine & Not known ${ }^{2}$ & $\begin{array}{l}\text { Hypertension, } \\
\text { also positive } \\
\text { for cocaine }\end{array}$ & A \\
\hline $\begin{array}{c}\text { Davis \& } \\
\text { Swalwell, } 1994\end{array}$ & $\begin{array}{l}42, \\
\text { male }\end{array}$ & Methamphetamine & Not known ${ }^{2}$ & Hypertension & NR \\
\hline $\begin{array}{c}\text { Davis \& } \\
\text { Swalwell, } 1994\end{array}$ & $\begin{array}{l}28, \\
\text { male }\end{array}$ & Methamphetamine & Not known ${ }^{2}$ & None & NR \\
\hline $\begin{array}{c}\text { Kim et al., } \\
1999\end{array}$ & $\begin{array}{c}37 \\
\text { male }\end{array}$ & Methamphetamine & Not known & None & A \\
\hline $\begin{array}{l}\text { Wako et al., } \\
2007\end{array}$ & $\begin{array}{c}39, \\
\text { male }\end{array}$ & Methamphetamine & Not known 3 & None & A \\
\hline $\begin{array}{l}\text { Wako et al., } \\
2007\end{array}$ & $\begin{array}{l}37, \\
\text { male }\end{array}$ & Methamphetamine & Not known 3 & Hypertension & B \\
\hline $\begin{array}{l}\text { Wako et al., } \\
2007\end{array}$ & $\begin{array}{c}38, \\
\text { male }\end{array}$ & Methamphetamine & Not known 3 & Hypertension & B \\
\hline $\begin{array}{l}\text { Wako et al., } \\
2007\end{array}$ & $\begin{array}{l}35, \\
\text { male }\end{array}$ & Methamphetamine & Not known ${ }^{3}$ & None & A \\
\hline $\begin{array}{l}\text { Wako et al., } \\
2007\end{array}$ & $\begin{array}{l}44, \\
\text { male }\end{array}$ & Methamphetamine & Not known 3 & Hypertension & A \\
\hline $\begin{array}{c}\text { Wako et al., } \\
2007\end{array}$ & $\begin{array}{c}44 \\
\text { male }\end{array}$ & Methamphetamine & Not known ${ }^{3}$ & Hypertension & A \\
\hline $\begin{array}{l}\text { Obioha, } \\
2009\end{array}$ & $\begin{array}{c}42, \\
\text { male }\end{array}$ & Methamphetamine & 2 days & None & A \\
\hline $\begin{array}{c}\text { Dihmis et al., } \\
1997\end{array}$ & $\begin{array}{l}27, \\
\text { male }\end{array}$ & Amphetamine & Not known ${ }^{2}$ & NR & A \\
\hline $\begin{array}{c}\text { Duflou \& Mark, } \\
2000\end{array}$ & $\begin{array}{c}29 \\
\text { male }\end{array}$ & MDMA (ecstasy) & $\begin{array}{c}\text { Possibly } 12 \\
\text { hours }^{2}\end{array}$ & None & A \\
\hline
\end{tabular}

Abbreviations: MDMA = 3,4-methylenedioxymethamphetamine; $\mathrm{NR}=$ not reported

${ }^{1}$ Stanford type A: All dissections involving the ascending aorta, regardless of the site of origin.

Stanford type B: All dissections not involving the ascending aorta

2 Patient deceased, intake detected by post-mortem toxicological screening

${ }^{3}$ Intake identified by drugs-of-abuse screening in urine

Table 5. Published cases of aortic dissections associated with methamphetamine, amphetamine and 3,4-methylenedioxymethamphetamine (ecstasy) 
Like cocaine, the amphetamines exert their stimulating effects by increasing available noradrenaline and dopamine in the brain synapses. However, in contrast to cocaine, the effect is predominantly mediated by enhancing the release of neurotransmitters from presynaptic neurons rather than by inhibiting the reuptake. Nevertheless, the final common pathway for cocaine and the amphetamines is activation of adrenergic alpha and beta receptors, thereby causing elevation of systemic blood pressure through vasoconstriction and increased ventricular contractility and heart rate, respectively (see also section 4.5.1).

It has not been stated in the literature whether specific antihypertensive drugs should be preferred for dissections caused by amphetamines. However, based on the mechanism of action, it seems reasonable to consider the same treatments for amphetamine- as for cocainerelated dissections. Thus, beta-blockers should be avoided because they would be expected to exacerbate, or at least not counteract, the tendency to cause vasoconstriction of the coronary and visceral arteries (see also section 4.5.1). The beta-blocker esmolol has nevertheless been suggested as the drug of choice in a recent case report (Obioha et al., 2009), but the authors of this report have, somewhat surprisingly, not discussed the potential risks with beta-blocker treatment in these patients.

\section{Conclusions}

The only drug group for which relatively clear-cut evidence of involvement in the formation and rupture of aortic aneurysms exists, is the glucocorticoids. In addition, there is inconsistent evidence from epidemiological studies regarding whether the various antihypertensive drug classes protect against or in fact may precipitate growth and ruptures of aortic aneurysms. Prospective controlled clinical trials in this area are urgently needed to elucidate this issue.

Drug groups implicated in aortic dissection include those known to increase systemic blood pressure, such as phosphodiesterase- 5 inhibitors like sildenafil, and vascular endothelial growth factor inhibitors like sorafenib, sunitinib and bevacizumab. Moreover, abrupt discontinuation of antihypertensive drugs known to cause rebound hypertension after cessation of therapy, such as beta-blockers, may also cause aortic dissection. In addition, single case reports exist for a few other drugs. Finally, illicit drugs such as cocaine, amphetamine, methamphetamine and ecstasy are associated with acute aortic dissections, with relative risk increases in the order of magnitude of about 2-3. Thus, the increased risk of aortic dissection for these substances is presumably considerably higher than for legal medicines.

\section{References}

Adkins, M.; Gaines, W.; Anderson, W.; Laub, G.; Fernandez, J. \& McGrath L. (1993). Chronic type A aortic dissection: an usual complication of cocaine inhalation. Ann Thorac Surg, Vol. 56, pp. 977-979

Aragon-Ching, J.B.; Ning, Y.-M. \& Dahut WL. (2008). Acute aortic dissection in a hypertensive patient with prostate cancer undergoing chemotherapy containing bevacizumab. Acta Oncol, Vol. 47, pp. 1600-1601

Barth, C.W.; Bray, M. \& Roberts, W. (1986). Rupture of the ascending aorta during cocaine intoxication. Am J Cardiol, Vol. 57, p. 496 
Baumgartner, F.J. \& Omari, B.O. (1997). Method of repair of cocaine-induced chronic type A aortic dissection. Ann Thorac Surg, Vol. 64, pp. 1518-1519

Bigi, M.A.; Aslani, A. \& Mehrpour M. (2008). Effect of chronic cocaine abuse on the elastic properties of the aorta. Echocardiography, Vol. 25, pp. 308-311

Blunt, D.M. \& Impallomeni, M.G. (2004). Warfarin-associated thoracic aortic dissection in an elderly woman. Age Ageing, Vol. 33, pp. 199-201

Boehrer, J.D.; Moliterno, D.J.; Willard, J.E.; Hills, L.S. \& Lange, R.A. (1993). Influence of labetalol on cocaine-induced coronary vasoconstriction in humans. Am J Med, Vol. 94, pp. 608-610

Boyle, J.; Loftus, I. \& Goodall, S. (1998). Amlodipine potentiates metalloproteinase activity and accelerates elastin degradation on a model of aneurysmal disease. Eur J Vasc Endovasc Surg, Vol. 16, pp. 408-414

Cohle, S.D. \& Lie, T.J. (1992). Dissection of the aorta and coronary arteries associated with acute cocaine intoxication. Arch Pathol Lab Med, Vol. 10, pp. 723-727

Daniel, J.C.; Huynh, T.T.; Zhou, W.; Kougias, P.; El Sayed, H.F.; Huh, J.; Coselli, J.S. \& Lin H. (2007). Acute aortic dissection associated with the use of cocaine. J Vasc Surg, Vol. 46, pp. $427-433$

Daugherty, A.; Rateri, D.L. \& Cassis, L.A. (2006). Role of the renin-angiotensin-aldosteron system in the development of abdominal aortic aneurysms in animals and humans. Ann N Y Acad Sci, Vol. 1085, pp. 82-91

Davies, C.J. \& Davies, D.M. (1998). Disorders of the peripheral vascular system. In: Davies's textbook of adverse drug reactions, Davies, D.M.; Ferner, R.E. \& de Glanville, H. (Eds.), pp. 169-189, Chapman \& Hall Medical, London

Davis, G.G. \& Swalwell, C.I. (1994). Acute aortic dissections and ruptured berry aneurysms associated with methamphetamine abuse. J Forensic Sci, Vol. 39, pp. 1481-1485

Dihmis, W.C.; Ridley, P.; Dhasmana, J.P. \& Wisheart, J.D. (1997). Acute dissection of the arota with amphetamine misue. BMJ, Vol. 314, p. 1665

Divakaran, V.; Mungee, S.; Salciccioli, L. \& Clark, L.T. (2007). Bedside ultrasound diagnosis of aortic dissection in a cocaine abuser. Eur J Intern Med, Vol. 18, pp. 595-596

Duflou, J. \& Mark, A. (2000). Aortic dissection after ingestion of "ecstacy" (MDMA). Am J Forensic Med Pathol, Vol.21, pp. 261-263

Eagle, K.A.; Isselbacher, E.M. \& DeSanctis, R.W. (2002). Cocaine-induced aortic dissection in perspective. Ciculation, Vol. 105, pp. 1529-1530

Eber, B.; Tscheliessnigg, K.-H.; Anelli-Monti, M.; Kaumann, P.; Lueger, A., Delgado, P.; Kullnig, P. (1993). Aortic dissection due to discontinuation of beta-blocker therapy. Cardiology, Vol. 83, pp. 128-131

Edeline, J.; Laguerre, B.; Rolland, Y.; Patard, J.-J. (2010). Aortic dissection in a patient treated by sunitinib for metastatic renal carcinoma. Ann Oncol, Vol. 21, pp. 186-187

Edwards, J. \& Rubin, R.N. (1987). Aortic dissection and cocaine abuse. Ann Intern Med, Vol. 107, pp. 779-780

Famularo, G.; Polchi, S.; Di Bona, G.; Manzara, C. (2001). Acute aortic dissection after cocaine and sildenafil abuse. J Emerg Med, Vol. 21, pp. 78-79

Fischer, A. \& Holroyd, P.R. (1992). Cocaine-associated dissection of the thoracic aorta. J Emerg Med, Vol. 10, pp. 723-727

Gadaleta, D.; Hall, M.H. \& Nelson, R.L. (1989). Cocaine-induced aortic dissection. Chest, Vol. 96, pp. 1203-1206 
Golden, M.A.; Vaughn, D.J.; Crooka, G.W.; Holland, A. \& Bavaria, J.E. (1997). Aortic dissection in a patient receiving chemotherapy for Hodgkin's disease. Angiology, Vol. 48, pp. 1063-1065

Grannis, F.W. Jr.; Bryant, C.; Caffaratti, J.D. \& Turner, A.F. (1988). Acute aortic dissection associated with cocaine abuse. Clin Cardiol, Vol. 11, pp. 572-574

Hackam, D.G.; Thiruchelvam, D. \& Redelmeier, D.A. (2006). Angiotensin converting enzyme inhibitors and aortic rupture: a population-based case-control study. Lancet, Vol. 368, pp. 659-665

Hayashi, H.; Kawamata, H.; Ichikawa, K.; Tajima, H. \& Kumazaki, T. (2004). Rupture of a thoracic aneurysm: a rare adverse reaction following systemic tissue plasminogen activator infusion. Heart Vessels, Vol. 19, pp. 208-211

Higashina, M.; Watanabe, H. \& Hashimoto, H. (1990). A successfully treated case of thoracic aneurysm during the course of SLE. Systemic vascular research committee of Japan, Annual report 1990, pp. 87-90

Hohm, S.P. (1995). A 28-year-old man with an aortic dissection and history of cocaine abuse. J Emerg Nurs, Vol. 21, pp. 199-201

Hollander, J.E. (2008). Cocaine intoxication and hypertension. Ann Emerg Med, Vol. 51 (suppl.), pp. S18-S20

Houston, M.C. \& Hodge, R. (1988). Beta-adrenergic blocker withdrawal syndromes in hypertension and other cardiovasular diseases. Am Heart J, Vol. 116, pp. 515-523

Hsue, P.Y.; Salinas, C.L.; Bolger, A.F.; Benowitz, N.L. \& Waters, DD. (2002). Acute aortic dissection related to crack cocaine. Circulation, Vol. 105, pp. 1592-1595

Hussain, K.M.A.; Chandna, H.; Santhanam, V.; Sehgal, S.; Jain, A. \& Denes, P. (1998). Aortic dissection in a young corticosteroid-treated patient with systemic lupus erythematosus. Angiology, Vol. 49, pp. 649-652

Ince, H. \& Nienaber, C.A. (2007). Diagnosis and management of patients with aortic dissections. Heart, Vol. 93, pp. 266-270

Johnson, J.A.; Callison, C. \& Miller, A.N. (2008). A 48-year-old man with paralysis and hypotension. Chest, Vol. 134, pp. 862-865

Kim, M.J.; Kim, M.S.; Han, S.W. \& Han, S.B. (1999). A case of acute dissection of the aorta associated with methamphetamine abuse [in Korean]. Journal of the Korean Society of Echocariography, Vol. 7, pp. 75-79

Kurata, N.; Tanai, K.; Kinashi, S. \& Irino, S. (1985). An autopsy case of systemic lupus erythematosus complicated by thoracic aortic aneurysm. Systemic vascular research committee of Japan, Annual report 1985, pp. 313-316

Lange, R.A.; Cigarroa, R.G.; Flores, E.D.; McBride, W.; Kim, A.S.; Wells, P.J.; Bedotto, J.B.; Danziger, R.S. \& Hills, L.D. (1990). Potentiation of cocaine-induced coronary vasoconstriction by beta-adrenergic blockade. Ann Intern Med, Vol. 112, pp. 897-903

Lange, R.A. \& Hills, D. (2001). Cardiovascular complications of cocaine use. N Engl J Med, Vol. 345, pp. 351-358

Lu, H.; Rateri, D.L.; Cassis, L.A. \& Daughtery, A. (2008). The role of the renin-angiotensin system in aortic aneurysmal diseases. Curr Hypertens Rep, Vol. 10, pp. 99-106

Madu, E.C.; Shala, B. \& Baugh, D. (1999). Crack-cocaine-associated aortic dissection in early pregnancy - a case report. Angiology, Vol. 50, pp. 163-168

McDermott, J.; Schuster, M.; Crummy, A. \& Archer, C. (1993). Crack and aortic dissection. Wis Med J, Vol. 92, pp. 453-455 
Mellingsæter, T.C.; Rørdam, O.M. \& Spigset, O. (2009). Association between aortic aneurysm rupture and short-term prednisolone use in two patients with dermatological disorders. J Europ Acad Dermatol Venerol, Vol. 23, pp. 585-586

Miyake, T. \& Morishita, R. (2009). Pharmacological treatment of abdominal aortic aneurysm. Cardiovas Res, Vol. 83, pp. 436-443

Nactnebel, A.; Stöllberger, C.; Ehrlich, M. \& Finsterer, J. (2006). Aortic dissection after sildenafil-induced erection. South Med J, Vol. 99, pp. 1151-1152

Obioha, C.C.; Engel, R.A. \& Ingall T. (2009). 42-year-old male methamphetamine user with dysarthria and facial drop. Mayo Clin Proc, Vol. 84, pp. 912-915

Ohara, N.; Miyata, T.; Sato, O.; Osihiro, H. \& Shigematsu, H. (2000a). Aortic aneurysm in patients with autoimmune diseases treated with corticosteroids. Int Angiol, Vol. 19, pp. 270-275

Ohara, N.; Miyata, T.; Kurata, A.; Oshiro, H.; Sato, O. \& Shigematsu, H. (2000b). Ten years' experience of aortic aneurysm associated with systemic lupus erythematosus. Eur J Vasc Endovasc Surg, Vol. 19, pp. 288-293

Om, A.; Porter, T. \& Mohanty, P.K. (1992). Transesophagal echocardiograpic diagnosis of acute aortic dissection complicating cocaine abuse. Am Heart J, Vol. 123, pp. 532-534

Perron, A.D. \& Gibbs, M. (1997). Thoracic aortic dissection secondary to crack cocaine ingestion. Am J Emerg Med, Vol. 15, pp. 507-509

Psaty, B.M.; Koepsell, T.D.; Wagner, E.H.; LoGerfor, J.P. \& Inui, T.S. (1990). The relative risk of incident coronary heart disease associated with recently stopping the use of betablockers. JAMA, Vol. 263, pp. 1653-1657

Rashid, J.; Eisenberg, M.J. \& Topol, E. (1996). Cocaine-induced aortic dissection. Am Heart J, Vol. 132, pp. 1301-1304

Reilly, J.M.; Savage, E.B.; Brophy, C.M. \& Tilson, M,D. (1990). Hydrocortisone rapidly induces aortic rupture in a genetically susceptible mouse. Arch Surg, Vol. 125, pp. 707-709

Reilly, J.M. (1996). Plasminogen activators in abdominal aortic aneurismal disease. Ann N Y Acad Sci, Vol. 800, pp. 151-156

Sato, O.; Takagi, A.; Miyata, T. \& Takayama, Y. (1995). Aortic aneurysm in patients with autoimmune disorders treated with corticosteroids. Eur J Vasc Endovasc Surg, Vol. 10, pp. 366-369

Serrano, C.; Suárez, C.; Andreu, J. \& Carles, J. (2010). Acute aortic dissection during sorafenib-containing therapy. Ann Oncol, Vol. 21, pp. 181-182

Seyama, K.; Muto, J. \& Furua, H. (1989) A case of upper abdominal aortic aneurysm associated with systemic lupus erythematosus. Jin To Touseki, Vol. 27, pp. 1139-1141

Sherzoy, A.; Sadler, D. \& Brown, J. (1994). Cocaine-related aortic dissection diagnosed by transesophagal echocardiography. Am Heart J, Vol. 128, pp. 641-643

Sica, D.A. (2006). Angiogenesis inhibitors and hypertension: an emerging issue. J Clin Oncol, Vol. 24, pp. 1329-1331

Simons, A.J.; Arazoza, E.; Hare, C.L.; Smulyan, H.; Lighty, G.W. Jr. \& Parker. F.B. Jr. (1992). Circumferential aortic dissection in a young woman. Am Heart J, Vol. 123, pp. 10771079

Singh, S.; Trivedi, A.; Adhikari, T.; Molnar, J.; Arora, R. \& Khosla, S. (2007). Cocaine-related acute aortic dissection: patient demographics and clinical outcomes. Can J Cardiol, Vol. 23, pp. 1131-1134 
Singh, A.; Khaja, A. \& Alpert, M.A. (2010). Cocaine and aortic dissection. Vasc Med, Vol. 15, pp. $127-133$

Smith, D.C. \& Hirst, A.E. (1979). Spontaneous aortic rupture associated with chronic steroid therapy for rheumatoid arthritis in two cases. AJR Am J Roentgenol, Vol.132, pp. 271273

Sthebens, W.E.; Delahunt, B.; Shirer, W.C. \& Naik, D.K. (1991) Aortic aneurysm in systemic lupus erythematosus. Histopathology, Vol. 22, pp. 275-277

Swalwell, C.I. \& Davis, G.G. (1999). Methamphetatmine as a risk factor for acute aortic dissection. J Forensic Sci, Vol. 44, pp. 23-26

Sweeting, M.J.; Thompson, S.G.; Brown, L.C.; Greenhalgh, R.M. \& Powell, J.T. (2010). Use of angiotensin converting enzyme inhibitors is associated with increased growth rate of abdominal aortic aneurysms. J Vasc Surg, Vol. 52, pp. 1-4

Szeberin, Z.; Firneisz, G.; Biro, G.; Szabo, G.V.; Sotonyi, P.; Windisch, M.; Krepuska, M.; Sipos, F.; Mihaly, E. \& Ascady, G. (2009). Surgical treatment of acute type B aortic dissection associated with use of cocaine [in Hungarian]. Orv Hetil, Vol. 150, pp. 129-131

Tiryakioglu, S.K.; Tiryakioglu, O.; Turan, T. \& Kumbay, E. (2009). Aortic dissection due to sildenafil abuse. Interactive Cariovasc Thorac Surg, Vol. 9, pp. 141-143

Veronese, M.L.; Mosenkis, A.; Flaherty, K.T.; Gallagher, M.; Stevenson, J.P.; Townsend, R.R. \& O'Dwyer, P.J. (2006). Mechanisms of hypertension associated with BAY- 43-9006 treatment. J Clin Oncol, Vol. 14, pp. 1363-1369

Wako, E.; LeDoux, D.; Mitsumori, L.; Aldea, G.S. (2007) The emerging epidemic of methamphetamine-induced aortic dissection. J Cardiac Surg, Vol. 22, pp. 390-393

Westover, A.N. \& Nakonezny, P.A. (2010). Aortic dissection in young adults who abuse amphetamines. Am Heart J, Vol. 160, pp. 315-321

Wilmink, A.B.M.; Vardulaki, K.A.; Hubbard, C.S.; Day, N.E.; Ashton, H.A.; Scott, A.P. \& Quick, C.R.G. (2002). Are all antihypertensive drugs associated with abdominal aortic aneurysms? J Vasc Surg, Vol. 36, pp. 751-757

Wu, S.; Chen, J.J.; Kudeka, A.; Lu, J. \& Zhu, X. (2008). Incidence and risk of hypertension with sorafenib in patients with cancer: a systematic review and meta-analysis. Lancet Oncol, Vol. 9, pp. 117-123

Zhu, X.; Wu, S.; Dahut, W.L. \& Parikh, C.R. (2007). Risks of proteinuria and hypertension with bevacizumab, an antibody against vascular endothelial growth factor: systematic review and meta-analysis. Am J Kidney Dis, Vol. 49, pp. 186-193 


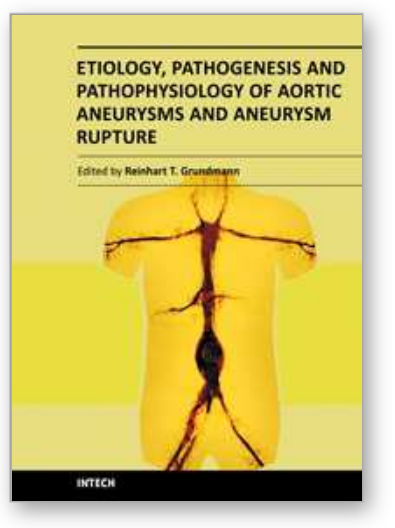

\section{Etiology, Pathogenesis and Pathophysiology of Aortic Aneurysms and Aneurysm Rupture}

Edited by Prof. Reinhart Grundmann

ISBN 978-953-307-523-5

Hard cover, 222 pages

Publisher InTech

Published online 27, July, 2011

Published in print edition July, 2011

This book considers mainly etiology, pathogenesis, and pathophysiology of aortic aneurysms (AA) and aneurysm rupture and addresses anyone engaged in treatment and prevention of AA. Multiple factors are implicated in AA pathogenesis, and are outlined here in detail by a team of specialist researchers. Initial pathological events in AA involve recruitment and infiltration of leukocytes into the aortic adventitia and media, which are associated with the production of inflammatory cytokines, chemokine, and reactive oxygen species. AA development is characterized by elastin fragmentation. As the aorta dilates due to loss of elastin and attenuation of the media, the arterial wall thickens as a result of remodeling. Collagen synthesis increases during the early stages of aneurysm formation, suggesting a repair process, but resulting in a less distensible vessel. Proteases identified in excess in AA and other aortic diseases include matrix metalloproteinases (MMPs), cathepsins, chymase and others. The elucidation of these issues will identify new targets for prophylactic and therapeutic intervention.

\section{How to reference}

In order to correctly reference this scholarly work, feel free to copy and paste the following:

Olav Spigset (2011). Drug-induced aortic aneurysms, ruptures and dissections, Etiology, Pathogenesis and Pathophysiology of Aortic Aneurysms and Aneurysm Rupture, Prof. Reinhart Grundmann (Ed.), ISBN: 978953-307-523-5, InTech, Available from: http://www.intechopen.com/books/etiology-pathogenesis-andpathophysiology-of-aortic-aneurysms-and-aneurysm-rupture/drug-induced-aortic-aneurysms-ruptures-anddissections

\section{INTECH}

open science | open minds

\author{
InTech Europe \\ University Campus STeP Ri \\ Slavka Krautzeka 83/A \\ 51000 Rijeka, Croatia \\ Phone: +385 (51) 770447 \\ Fax: +385 (51) 686166 \\ www.intechopen.com
}

\author{
InTech China \\ Unit 405, Office Block, Hotel Equatorial Shanghai \\ No.65, Yan An Road (West), Shanghai, 200040, China \\ 中国上海市延安西路65号上海国际贵都大饭店办公楼405单元 \\ Phone: $+86-21-62489820$ \\ Fax: $+86-21-62489821$
}


(C) 2011 The Author(s). Licensee IntechOpen. This chapter is distributed under the terms of the Creative Commons Attribution-NonCommercialShareAlike-3.0 License, which permits use, distribution and reproduction for non-commercial purposes, provided the original is properly cited and derivative works building on this content are distributed under the same license. 